\title{
Basin margin sediment wedge build out of the Eastern Niger Delta: application of shelf-edge trajectory pattern studies
}

\author{
Okwudiri A. Anyiam ${ }^{1}$ (D) Nicholas Hoggmascall ${ }^{2}$. Daniel K. Amogu²
}

Received: 15 July 2020 / Accepted: 25 January 2021 / Published online: 18 February 2021

(c) The Author(s) 2021

\begin{abstract}
The understanding of how basin margin sediment wedge builds out causes shelf-edge migration with time is approached based on shelf-edge trajectory pattern analysis using a high-resolution mega-merge seismic data from the eastern Niger Delta, Nigeria. The study focuses on a seismic dip transect traversing the Greater Ughelli, Central Swamp, Coastal Swamp and the Shallow Offshore Depobelts of the Niger Delta. On the regional dip transects, shelf-edge sediments occur as clinoformbearing wedges at and immediately updip of the shelf-slope break. The shelf edge is deeply buried $(>2-4 \mathrm{~s}$, twt), around the Greater Ughelli and Central Swamps. But with changing structural style, sudden change of ascending shelf edge around the Central Swamp was observed. The huge listric growth fault in the Coastal Swamp; around Bonny area, once again cut the shelf edge into half, rotated it along the listric fault and buried it distally. Several depositional packages show low to moderate ascending shelf-edge trajectory with progradational to aggradational clinoform growth that is characterized by thin sand sheets across most of the shelf and upper slope, though few are also characterized by progradational clinoform growth with thick sand on the shelf, upper-tolower slope and basin floor. The deposition is usually on the Outer Shelf Terrace (OST) which is regressive in a flat and rising trajectory style. This study has demonstrated that accommodation and sediment flux are the dominant controls on how the study basin's sediment wedge built out, whereby limited accommodation promotes sediments with significant shelf-edge advance and descending trajectories, while increasing accommodation promotes ascending trajectories and increased deposition on the outer shelf. The greater sediments on the Outer Shelf Terrace and the shelf margin than on the slope gives more hydrocarbon prospectivity search around the outer shelf and shelf margin.
\end{abstract}

Keywords Shelf margin $\cdot$ Sediment supply $\cdot$ Shelf edge trajectory

\section{Introduction}

Apart from the deepwater oil wells of the offshore Niger Delta, most oil and gas wells are concentrated within the shallow depths of the shelf. The sediment package is relatively small in the Northern Delta depobelt, but gradually increased basinward as prograding sediments build on the hanging wall of the listric faults. These hanging wall sediments build out get deeply buried as younger faults continue to cut into previous walls until the sediments get to the edge of the shelf. The shelf-margin deep packages form potential

Okwudiri A. Anyiam

okwudiri.anyiam@unn.edu.ng

1 Department of Geology, University of Nigeria, Nsukka Enugu, Nigeria

2 Shell Petroleum Development Company, PortHarcourt City, Nigeria hydrocarbon plays in the Niger Delta Basin, especially around the Central and Coastal Swamp depobelts. Recently, much discussion has centered on the deeply buried 'shelf margin' plays in the delta. In these settings, calibration by well penetrations is rare and much of our understanding of prospectivity relies on seismic imaging below $3 \mathrm{~s}(\mathrm{twt})$. The shelf-margin sediments are formed when there is relative sea level fall of the lowstand with corresponding high sediment supply (Mellere et al. 2002). The sediments are mainly terrigenous clastics derived from the eroded exposed shelf/ coastal plain and delivered to the regressive shelf (Burgess et al. 2008). Depending on the sediment flux and gradient of the shelf, these coastal plain facies can move beyond the shelf or near the shelf break (Coleman et al. 1983; Sutter and Berryhill 1985; Coleman and Roberts 1988), from where they can be deposited on the shelf slope and deep marine. It is important to understand the evolution of shelf-edge sediments so as to predict the delivery of sediments beyond the 
mouth of the delta. On a scarp shelf slope, such sediments bypass the terrestrial topset area and are delivered to the top of the continental slope, from where it can be routed through several conduits down to deep-marine environment (Porebski and Steel 2001). The sediments are deposited as turbidites in the deep marine depositional setting, which are the major target for hydrocarbon exploration (Mayall et al. 1992; Hart et al. 1997). The route through which these sediments migrate from the shelf, through the slope to the deep marine, defines its trajectory (Steel and Olsen 2002; Sydow et al. 2003). It varies in its inclination or slope (HellandHanson and Martinsen 1996), as a result of varying relative sea level change and sediment flux (Steel and Olsen 2002; Hampson and Storms 2003).

The present study focuses on a seismic/geological dip transect of the eastern Niger Delta, traversing from the Greater Ughelli, through the Central Swamp and Coastal Swamp to the Shallow Offshore. In such a dip section, the delta progradation can be traced from the Oligocene south to the Pliocene and shows some distinctive features. It is aimed at using shelf-edge trajectory pattern analysis to understand how basin margin sediment wedge build out cause shelfedge migration with inferences on creation of accommodation and sedimentation rate. The study also seeks to describe the trap geometry of such basin margin settings along the line of section, provide evidence of play testing and to comment on the opportunities.

\section{Geological setting}

The Niger Delta is the arcuate delta of the Niger River that emptied on the southern Atlantic Ocean. It extended throughout the Niger Delta of Nigeria (Klett et al. 1997) and forms one of the most prominent passive margin sediment wedges [PMSW] on the western coast of Africa. The delta has been an active outbuilding wedge since the Oligocene.

The Niger Delta Basin lies in the southern part of a larger tectonic structure, the Benue Trough. It is an extensional basin which is bounded by the Cameroon Volcanic Line and the transform passive continental margin (Short and Stauble 1967). The basin was formed as a result of a failed triple rift system during the separation of the South American plate and the African plate. The rifting of the Niger Delta Basin started in the late Jurassic and ended in the mid Cretaceous which gave rise to several faults. During early Paleocene, there was a significant shoreline regression which resulted in the deposition of the Akata Formation. This was overlain by the paralic Agbada Formation during the Eocene. The high density Agbada clastic created loading that caused the Akata Shale to be under-compacted and squeezed into shale diapirs (Tuttle et al. 1999). Then, in the Oligocene, the continental
Benin Formation was deposited, which is still being deposited today (Fig. 1)

The sediment fill in the Niger Delta Basin is characterized by three diachronous lithostratigraphic units that range from the Eocene to Recent (Fig. 2). These three litho units indicate that the basin experienced an overall regression through time as the sediments go from deep sea mudstones and shales to fluvial denser sand sized grains. The Akata Formation is composed of thick shales, turbidite sands with small amounts of silt and clay. The clay content is ductile as it was squeezed into shale diapirs in the basin. The Akata shales are under-compacted, over-pressured and underlay the Agbada Formation and was formed an anoxic conditions. The thickness of the formation is estimated to be up to $7000 \mathrm{~m}$ (Doust and Omatsola 1989; Tuttle et al. 1999). The Agbada Formation is of marine paralic facies consisting of alternating sands, silts and shales. It is characterized by coarsening upward-ward grain size and bed thickness successions. This formation is the major hydrocarbon-bearing facies in the basin and it is estimated to be $3700 \mathrm{~m}$ thick (Turtle et al. 1999). The majority of the structural traps of the Niger Delta were developed during syn-sedimentary deformation of the Agbada paralic succession (Evamy et al. 1978). The Oligocene Benin Formation is the shallowest unit in the basin and composed of continental flood plain sands and alluvial deposits. It is estimated to be up to $2000 \mathrm{~m}$ thick (Tuttle et al. 1999).

\section{Materials and method}

The study was done on high-resolution traverse dip section of the eastern Niger Delta mega-merged seismic data analyzed using Shell GeoSigns nDI software. The mega merge was loaded as a 3D seismic volume with infill 2D seismic lines to compensate for areas without 3D data coverage. It was then loaded as a Regional Trace Volume to merge the individual seismic volumes. Amplitude balancing was done between the various seismic vintages by applying additional gain to individual volumes via 3D multi-volume manager. Also, amplitude balancing filters was applied to the entire Regional Trace Volume for better viewing. The interpretation was carried out on the 2D traverse seismic section, but features on an area of interest (AOI) of the data were observed on a three-dimensional (3D) volume view. The dip section which covers the different depobelts of the Niger Delta is oriented roughly perpendicular to the advancing shoreline and shelf edge and was used for the detailed clinoform analysis. A calibration well list of about 9 well logs through the seismic traverse was made to establish an isochronous framework for the dip section. Relatively conformable packages were delineated on the seismic data by picking major unconformities identified from reflector terminations, change in seismic facies character, or choosing 


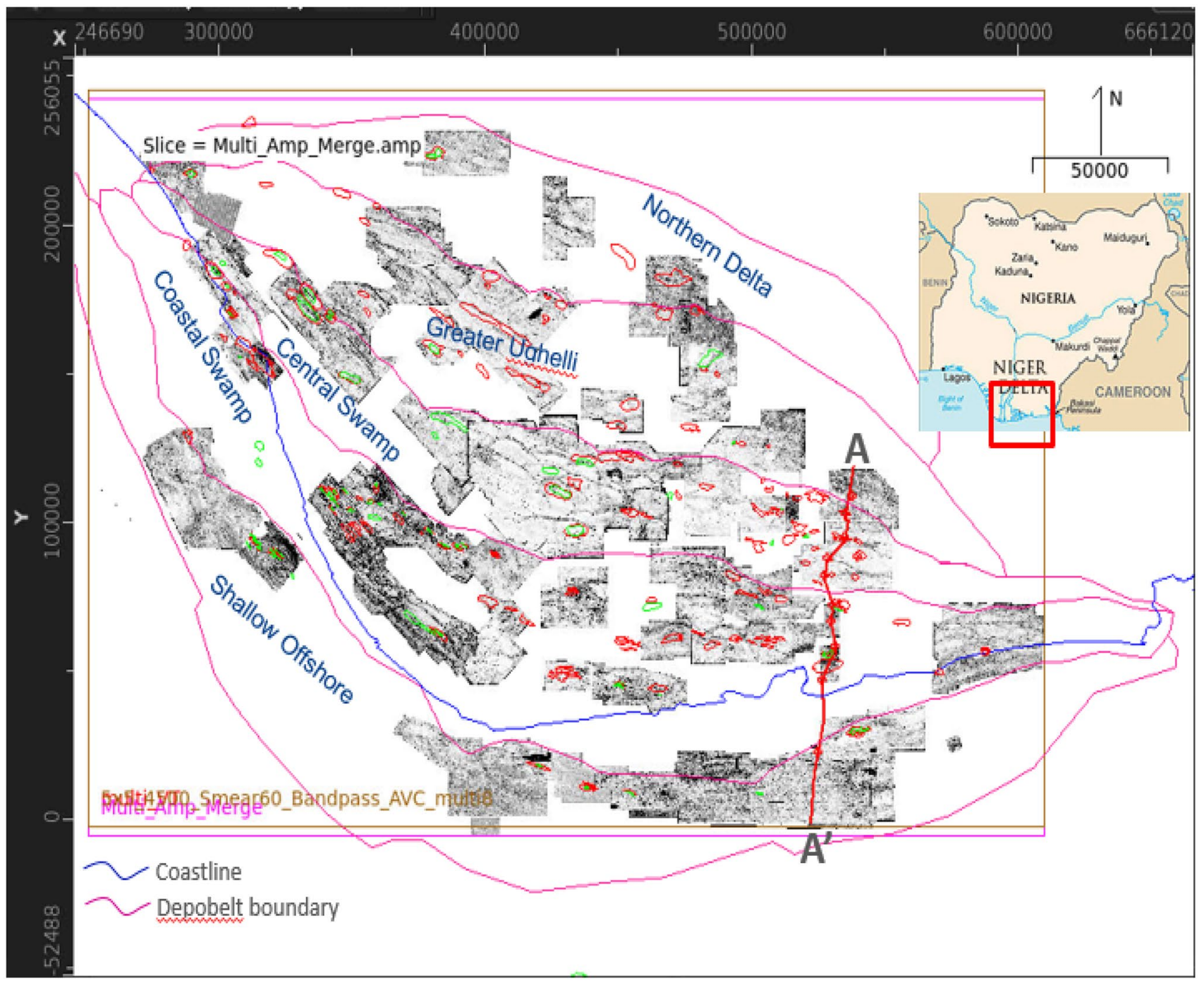

Fig. 1 Map view of the seismic mega-merge at $2 \mathrm{~s}$ (twt) Slice, showing dip transects (A-A')—Greater Ughelli to Shallow Offshore (Inset: Map of Nigeria, showing the Niger Delta)

significant boundaries from the well-log data. The faults were then picked and structural restoration across main faults was performed to establish a tectonostratigraphic framework of the dip section. A seismic facies analysis was also done to define thinning, unconformity, layer cake and strata terminations to define seismic sequence stratigraphic geometries. The position of the shelf edge through time was marked by the point of maximum curvature between the topset and foreset (Pirmez et al. 1998; Helland-Hansen and Hampson 2009; Anell and Midtkandal 2017). The position was identified as a point perpendicular to the intersection of straight lines extrapolated from the inflection point of the topset and foreset of the clinoform, with few uncertainties. Then, the trap geometries along the line of section were also identified and described to provide evidence of play testing.

\section{Results and discussion}

\section{Description of sequence}

The results show the presence of six distinct sequence geometries (Figs. 3, 4). They are characterized by sheet geometry landward (Greater Ughelli and Central Swamp) and are wedge shaped basinward (Coastal and Shallow Offshore). Internally, the reflectors are wavy to parallel and are predominantly semi-continuous to continuous with low to moderate amplitude in sequences \#1 to \#3. The top of Seq.\#4 in Greater Ughelli and Central Swamp shows parallel to wavy while the base, which is erosional shows wavy to chaotic internal configuration, typical of mass transport deposits. In well data, such chaotic reflectors are described as mudstones with intercalations of sands 


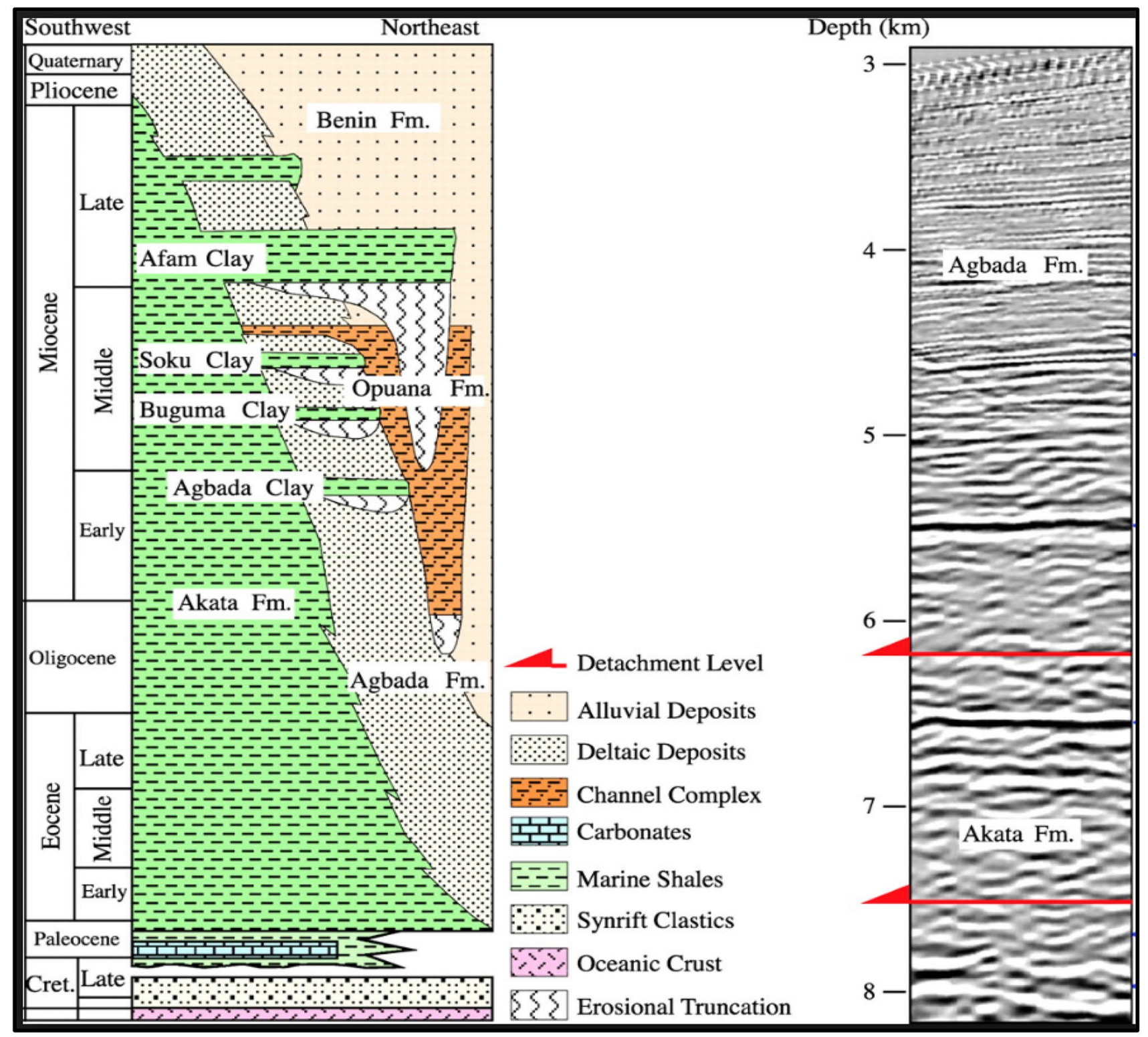

Fig. 2 Schematic diagram of the regional stratigraphy of the Niger Delta and variable density seismic display of the main stratigraphic units (Corredor et al. 2005)

which are strongly affected by syn-sedimentary deformations (Berton and Vesely 2016). Sequences \#5 and \#6 also show sheet external forms proximally, which grades to clinoform-bearing wedges distally, especially around the Shallow Offshore (Figs. 3, 4). The reflectors are sub-parallel to parallel landward and parallel to divergent to oblique basinward towards the shelf edge (Figs. 3, 4).

The gamma ray log signature through Sequences \#1 to \#3 show alternation of sand and shale with moderate netto-gross; typical of inner to mid-shelf environment in the Greater Ughelli and Central Swamps. Seq. \#3 thins landward due to the erosional truncation, but thickens basinward (Coastal and Shallow Offshore) because of the accommodation created on the hanging wall of the huge down-to-basin growth faults; resulting in the formation of extensional rollover topset structures (Figs. 3, 4). The deeper burial of the sediments on the hanging wall of the down-tobasin fault in the Coastal Swamp gradually reduces the netto-gross towards the offlap break (shelf edge) in the Shallow Offshore.

Also, sequences \#4 and \#5 show high net-to-gross (N/G) of the alluvial plain from the Greater Ughelli to Coastal Swamp and grades through mid to outer shelf with moderate net-to-gross (outer terrace) in the Shallow Offshore. The deposits beyond the shelf edge show very low net-to-gross with isolated sands in the mud dominated slope. Seq. \#6 


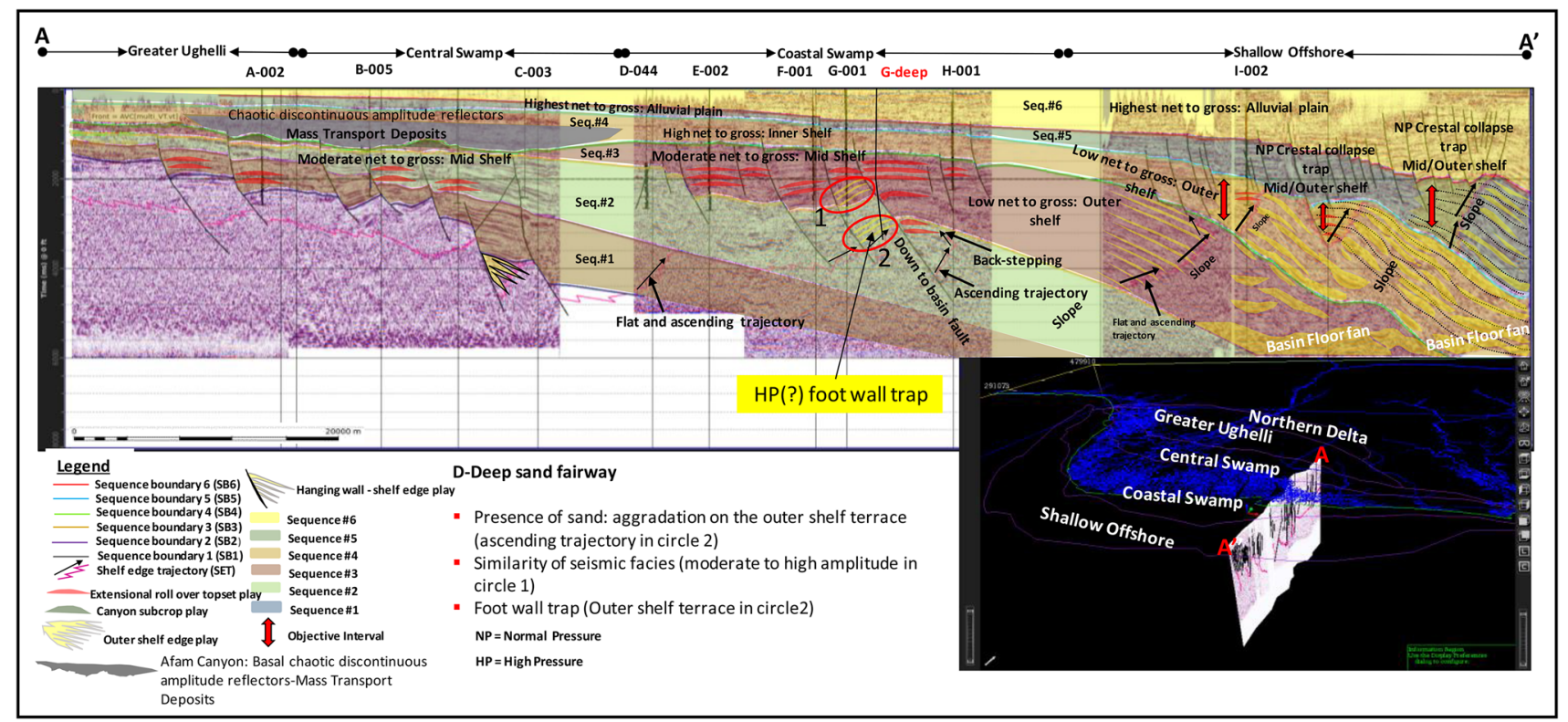

Fig. 3 Interpreted 2D regional dip line (Traverse $\mathrm{A}-\mathrm{A}^{\prime}$ ), showing interpreted sequence geometries, faults, events, GDEs and different play segments (Red circle 1: sand presence calibrated by G-001 well;
Red circle 2: sand prediction in G-deep well by aggradation and similar seismic facies with G-001 well)

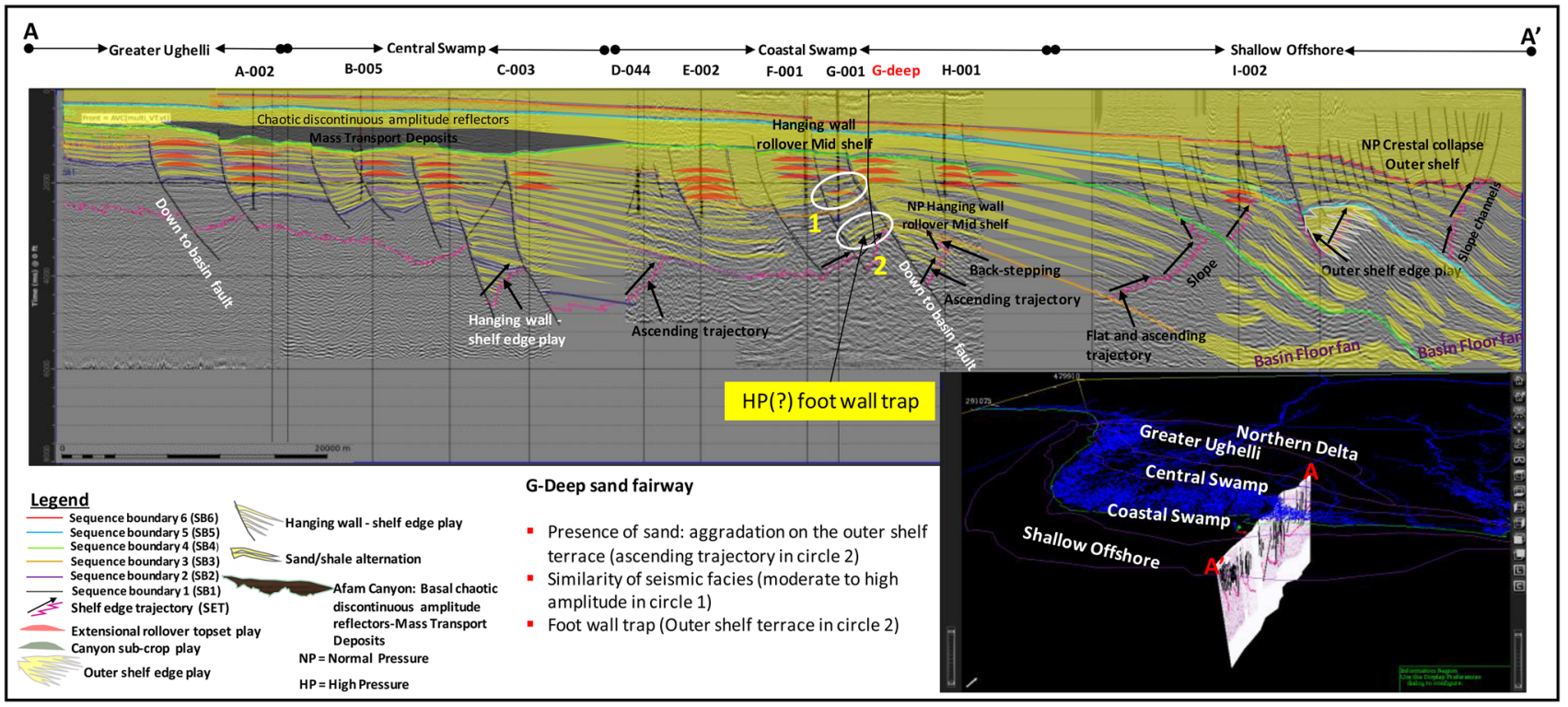

Fig. 4 Interpreted 2D regional dip line (Traverse A-A'), showing interpreted faults, events, GDEs and different play segments (White circle 1: sand presence calibrated by G-001 well; white circle 2: sand

started from the Central Swamp proximally and thickens distally at the Shallow Offshore (Figs. 3, 4). This is due to the accommodation created by the crestal collapse synthetic and antithetic faults that were initiated by the compaction of the prodelta muds. prediction in G-deep well by aggradation and similar seismic facies with G-001 well)

\section{Shelf-margin development}

The shelf-edge trajectory analysis shows that around the Greater Ughelli and Central Swamp, the shelf edge is buried deep ( $>2-4 \mathrm{~s}$, twt) below the poor seismic resolution 
(Figs. 3, 4). But with changing structural style, there is sudden change from deeply flat to ascending shelf edge around the Central Swamp. The huge listric growth fault in the Coastal Swamp (Figs. 3, 4); around Bonny Island, once again buried the shelf edge (Sequences \#1 and \#2); cutting it into half, rotated along the fault and buried deeper (Fig. 3). Seq. \#2 shows an ascending shelf-edge trajectory (early sea level rise), followed by backstepping signature which indicates transgression due to sea level rise. Relative sea level fall initiated an active down-to-basin fault that gave rise to the basinward build out of the shelf edge in sequence \#3 (Mid-Inner Shelf) (Fig. 5). This is followed by sea-level rise, creating sets of backstepping clinoforms; which indicates retrogradation-dominated margin that has landward shelf-edge imprint; with mud dominated slope.

The basin margin build out in this sequence is characterized by lower prograding (flat and ascending) and upper aggrading (ascending) clinoform growth (Fig. 5). The lowangle upward prograding shelf-margin part of this package occurred during sea-level fall (or slight rise); with prograding high shelf-edge sand-mud submarine canyon system that has moderate sand-shale ratios. Also, the steeply upward aggrading clinoforms were formed during sea-level rise; with aggradation-dominated margins associated with sandrich submarine fans with moderate sand-shale ratios and mud dominated Mass Transport Complex (MTC). These depositions are usually on the Outer Shelf Terrace (OST) due to high sediment flux enough to withstand the rising sea level. In Seq. \#4, the shelf edge is cut into half by one of the longest collapse crestal faults, rotating it along the fault plane and buried it deeper (Fig. 6). Both sequences \#4 and \#5 show low to moderate ascending (rising) shelf-edge trajectories with progradational to aggradational clinoform growth that is characterized by thin sand sheets across most of shelf and upper slope. The aggradational clinotherm sets occur with thick shale between sands that are usually stormwave generated. Such gently ascending trajectories (Fig. 4) also contribute to a significant basin-floor fan development (Johannessen and Steel 2005). The number of shelf delta successions and their thicknesses are also greater for more steeply rising (ascending) shelf-edge trajectories than they are for falling (descending) or gently rising (flat and ascending) trajectories.

Overall, the clinoforms of the packages preserve a semisigmoidal shape with thick topset successions. They have mildly chaotic internal reflectors on the topsets and foresets with shelf-edge trajectories that show generally positive (ascending) trends. The trajectory indicates a system with generally continuous rising relative sea level with good accommodation, probably related to the tectonic subsidence (Anell and Midtkandal 2017) in the Niger Delta.

All the sequences with flat and ascending (rising) shelfedge trajectories are indications that the eastern Niger Delta is a sediment supply-dominated margin. This kind of margin is linked to sea-level fall and rise or still stand with progradation-aggradation dominant shelf-edge and mud-prone deposition (Carvajal and Steel 2006). This supply-dominated margin is continuous across the entire clinoform from top to bottom, despite times of stronger accommodation influence on some clinoforms (Fig. 5). The shelf-edge deltas of

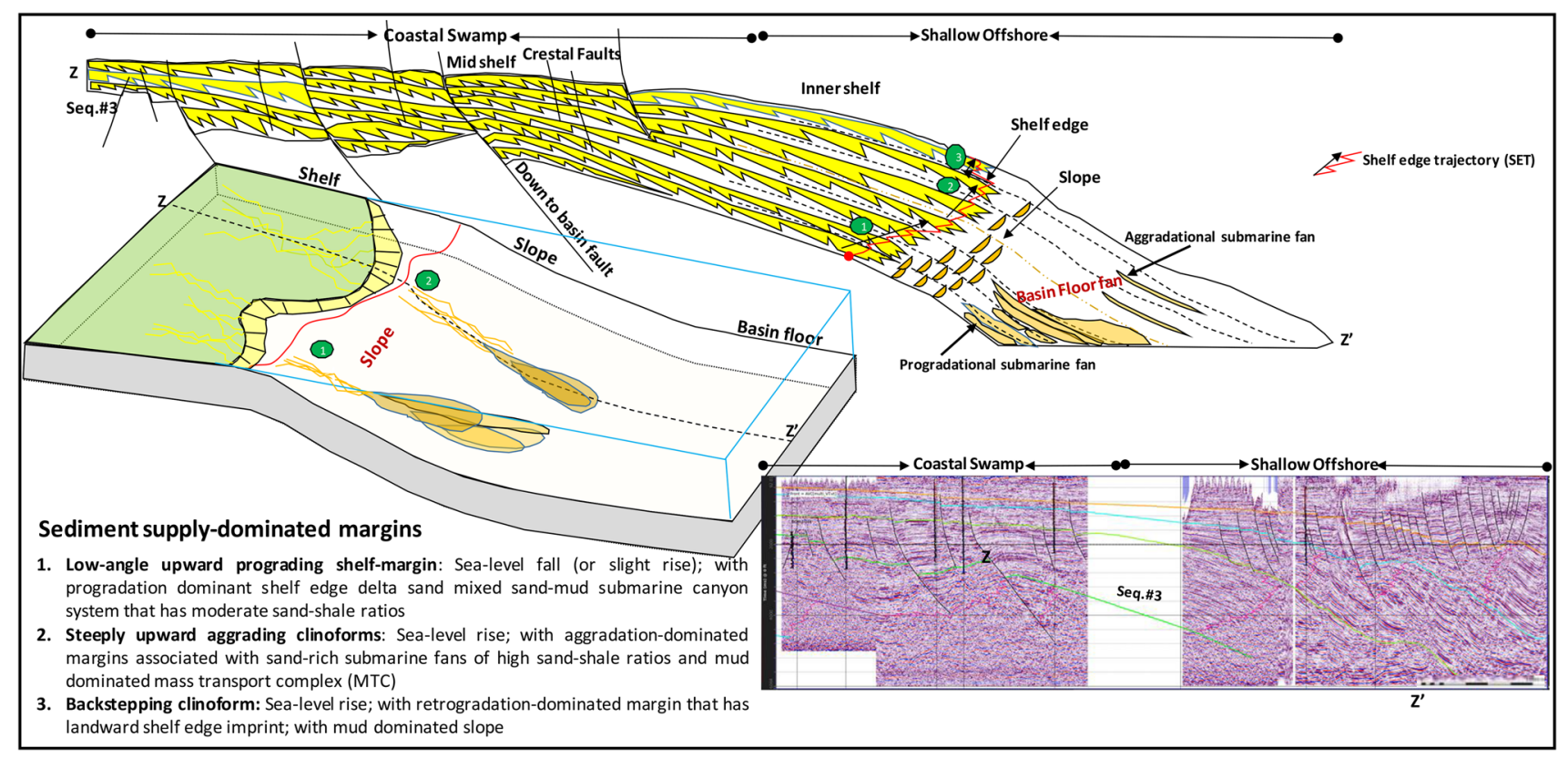

Fig. 5 Schematic three-dimensional block diagram with projected dip cross sections (Z-Z') of clinoforms in Sequence \#3) sediment supplydominated margins 


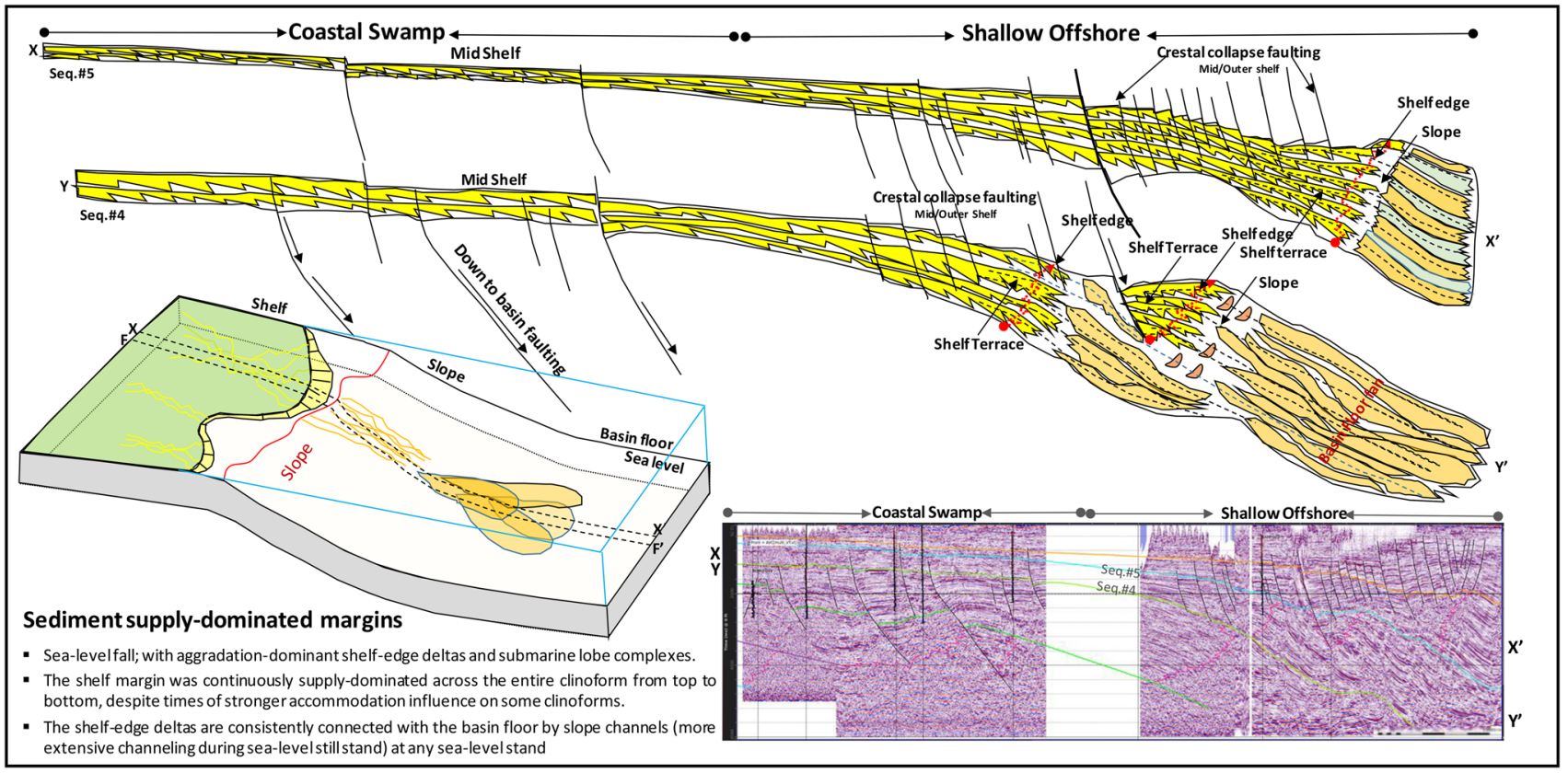

Fig. 6 Schematic three-dimensional block diagram with projected dip cross sections ( $\mathrm{X}-\mathrm{X}^{\prime}$ and $\left.\mathrm{Y}-\mathrm{Y}^{\prime}\right)$ of clinoforms in Sequences \#4 and \#5) sediment supply-dominated margins

this margin are consistently connected with the basin floor through slope channels at sea-level stand (Koo et al. 2016). This implies that there is a consistent link between shelfedge deposits and basin floor despite the reworking of the shelf-edge progradation by waves and tides. The channels are more on the slopes of the flat and ascending (low-angle prograding) shelf-edge trajectory (Fig. 5), through which much sediments are routed to the basin floor than in ascending trajectory. The play segments identified are mainly fault dependent (Figs. 3, 4), which includes extensional rollover plays, high pressure outer shelf-edge plays, hanging wall shelf-edge plays and slope channel/basin floor turbidites. It is also observed that these shelf-edge plays are typically buried beneath a thick shelf and alluvial plain overburden where well penetrations are rare. Because of this, prediction of reservoir presence relies mainly on seismic reflector characters. For example, in Figs. 3 and 4, the presence of sand was predicted in the D-deep well using the adjacent calibrated D-001 well because of similarity in seismic facies and likely aggradation of sand-rich sediments on the outer shelf terrace (ascending trajectory) of the D-deep well.

\section{Conclusions}

An interpretation of the dip section of the mega-merge seismic from eastern Niger Delta was carried out in this study. Six distinct sequence geometries were delineated; characterized by sheet geometry landward (Ughelli and Central
Swamp) and wedge shaped basinward (Coastal Swamp and Shallow Offshore). The shelf-edge trajectories show flat and ascending, ascending and backstepping clinoforms corresponding to low-angle prograding, aggrading and retrograding, respectively. The variation in trajectory inclination is because of varying sediment supply and relative sea level. The dip section also indicates a sediment-supply dominated margin. Sediments are routed to the basin floor through the slope channels during progradation while more sands and shales are stacked on the Outer Shelf Terrace (OST) during aggradation. The play segments are mainly extensional rollover plays, high pressure outer shelf-edge plays, hanging wall shelf-edge plays and slope channel/basin floor turbidites. This study has demonstrated that accommodation and sediment flux are the dominant controls on how the sediment wedge built out in the Niger Delta Basin. It confirms that limited accommodation promotes sediments with significant shelf-edge advance and descending trajectories, while increasing accommodation promotes ascending trajectories and increased deposition on the outer. It also helps to predict the reservoir presence and hydrocarbon plays vertically and laterally, especially in such settings where calibrations by well penetrations are rare.

Funding The research was carried out during the first author's sabbatical placement with the Shell Petroleum Development Company (SPDC), Port Harcourt, Nigeria. By so, they are the sponsor. The authors acknowledge Shell Petroleum Development Company Nigeria for the hosting and sponsorship of this research. 
Open Access This article is licensed under a Creative Commons Attribution 4.0 International License, which permits use, sharing, adaptation, distribution and reproduction in any medium or format, as long as you give appropriate credit to the original author(s) and the source, provide a link to the Creative Commons licence, and indicate if changes were made. The images or other third party material in this article are included in the article's Creative Commons licence, unless indicated otherwise in a credit line to the material. If material is not included in the article's Creative Commons licence and your intended use is not permitted by statutory regulation or exceeds the permitted use, you will need to obtain permission directly from the copyright holder. To view a copy of this licence, visit http://creativecommons.org/licenses/by/4.0/.

\section{References}

Anell I, Midtkandal I (2017) The quantifiable clinothem-types, shapes and geometric relationships in the Plio-Pleistocene Giant Foresets Formation, Taranaki Basin New Zealand. Basin Res 29(1):277-297

Berton F, Vesely FF (2016) Seismic expression of depositional elements associated with a strongly progradational shelf margin: Northern Santos Basin, Southeastern Brazil. Braz J Geol 46(4):585-603

Burgess PM, Steel RJ, Granjeon D (2008) Stratigraphic forward modelling of basin-margin clinoform systems: implications for controls on topset and shelf width and timing of formation of shelf edge deltas. Recent advances in models of siliciclastic shallow-marine stratigraphy. SEPM Special Publication No. 90, Copyright (C) 2008 SEPM (Society for Sedimentary Geology), ISBN 978-1-56576131-5, pp 35-45.

Carvajal CR, Steel RJ (2006) Thick turbidite successions from supply-dominated shelves during sea-level highstand. Geology 34:665-668

Coleman JM, Prior DB, Lindsay JF (1983) Deltaic influences on shelf edge instability processes. In: Stanley DJ, Moore GT (eds) The shelf break: critical interface on continental margins, vol 33. SEPM Special Publication, Tulsa, pp 121-138

Coleman JM, Roberts HH (1988) Sedimentary development of the louisiana continental shelf related to sea level cycles. Geo-Mar Lett 9:161-170

Corredor F, Shaw JH, Bilotti F (2005) Structural styles in the deepwater fold and thrust belts of the Niger Delta. AAPG Bull 89(6):753-780

Doust H, Omatsola E (1989) The Niger Delta: hydrocarbon potential of a major tertiary Delta Province. Assoc Petroleum GeolMem 48:203-212

Doust H, Omatsola E (1990) Niger Delta. In: Edwards JD, Santogrossi PA (eds) Divergent/passive margin basins. AAPG Mem 45, 201-238

Evamy BD, Haremboure J, Kamerling P, Knaap WA, Molloy FA, Rowlands PH (1978) Hydrocarbon habitat of tertiary Niger Delta. Am Asso Pet Geol Bull 62:277-298

Hampson GJ, Storms JE (2003) Geomorphological and sequence stratigraphic variability in wave-dominated, shoreface-shelf parasequences. Sedimentology 50:667-701

Hart BS, Sibley DM, Flemings PB (1997) Seismic stratigraphy, facies architecture, and reservoir character of a pleistocene shelf-margin delta complex, Eugene Island Block 330 Field, offshore Louisiana. AAPG Bull 81:380-397
Helland-Hansen W, Martinsen OJ (1996) Shoreline trajectories and sequences: description of variable depositional-dip scenarios. J Sediment Res 66:670-688

Helland-Hansen W, Hampson GJ (2009) Trajectory analysis: concepts and applications. Basin Res 21:454-483

Hospers J (1965) Gravity field and structure of the Niger Delta, Nigeria, West Africa. GeolSoc Am Bull 76(4):407-422

Johannesson EP, Steel RJ (2005) Shelf-margin clinoforms and prediction of deepwater sands. Basin Res 17:521-550. https://doi.org/1 0.1111/j.1365-2117.2005.00278.x

Klett TR, Ahlbrandt TS, Schmoker JW, Dolton JL (1997) Ranking of the world's oil and gas provinces by known petroleum volumes. U.S. Geological Survey Open-file Report, 97-463.

Koo WM, Olariu C, Steel RJ, Olariu MI, Carvajal CR, Kim W (2016) Coupling between shelf-edge architecture and submarine-fan growth style in a supply-dominated margin. J Sediment Res 86:613-628

Mayall MJ, Yeilding CA, Oldroyd JD, Pulham AJ, Sakurai S (1992) Facies in a shelf-edge delta-an example from the subsurface of the Gulf of Mexico, Middle Pliocene, Mississippi Canyon, Block 109. AAPG Bull 76:435-448

Mellere D, Plink-Björklund P, Steel R (2002) Anatomy of shelf deltas at the edge of a prograding Eocene shelf margin, Spitsbergen. Sedimentology 49:1181-1206. https://doi.org/10.104 6/j.1365-3091.2002.00484.x

Pirmez C, Pratson LF, Steckler MS (1998) Clinoform development by advection-diffusion of suspended sediment: modeling and comparison to natural systems. J Geophys Res Solid Earth 1978-2012(103):24141-24157

Porebski SJ, Steel RJ (2001) Delta types and sea level cycle. 2001 AAPG annual convention June 3-6, 2001, Denver Colorado. Off progr 10:A160

Short KC, Stauble J (1967) Outline geology of the Niger Delta. Am Asso Petrol Geol Bull 5:761-779

Steel RJ, Olsen T (2002) Clinoform trajectories and deepwater sands. In: Armentrout JM, Rosen NC (eds) Sequence stratigraphic models for exploration and production: evolving methodology, Emerging models and application histories. Spec. Publ, GCS-SEPM, pp 367-381

Suter JR, Berryhill HL (1985) Late quaternary shelf-margin deltas, northwest Gulf of Mexico. AAPG Bull 69:77-91

Sydow JC, Finneran J. Bowman AP (2003) Stacked shelf edge reservoirs of the Columbus Basin, Trinidad, West Indies. In: Roberts HH, Rosen NC, Fillon RH Anderson JB (eds) Shelf-margin deltas and linked down slope petroleum systems: global significance and future exploration potential. Gulf Coast Section SEPM 23rd annual research conference, pp 411-465.

Tuttle M, Charpentier R, Brownfield M (1999) The Niger Delta petroleum system; Niger Delta Province, Nigeria, Cameroon and Equatorial Guinea, Africa. USGS Open-File Report. 99-50-H, p 65

Xiao H, Suppe J (1992) Origin of rollovers. Am Asso Petrol Geol Bull 76:509-529

Publisher's Note Springer Nature remains neutral with regard to jurisdictional claims in published maps and institutional affiliations. 